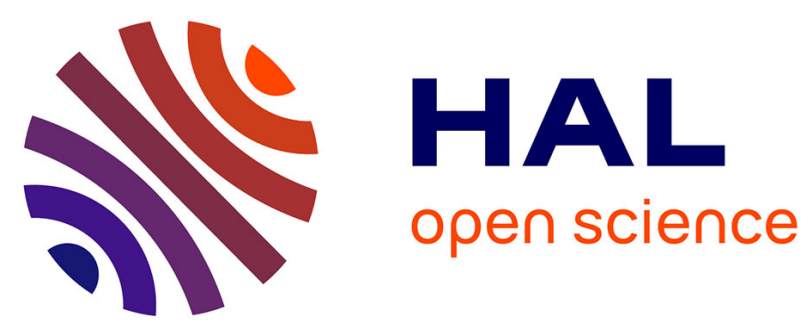

\title{
Aspergillus section Flavi and aflatoxins in Algerian wheat and derived products
}

Amar Riba, Noureddine Bouras, Salim Mokrane, Florence Mathieu, Ahmed Lebrihi, Nasserdine Sabaou

\section{- To cite this version:}

Amar Riba, Noureddine Bouras, Salim Mokrane, Florence Mathieu, Ahmed Lebrihi, et al.. Aspergillus section Flavi and aflatoxins in Algerian wheat and derived products. Food and Chemical Toxicology, 2010, vol. 48, pp. 2772-2777. 10.1016/J.FCT.2010.07.005 . hal-00725443

HAL Id: hal-00725443

https://hal.science/hal-00725443

Submitted on 27 Aug 2012

HAL is a multi-disciplinary open access archive for the deposit and dissemination of scientific research documents, whether they are published or not. The documents may come from teaching and research institutions in France or abroad, or from public or private research centers.
L'archive ouverte pluridisciplinaire HAL, est destinée au dépôt et à la diffusion de documents scientifiques de niveau recherche, publiés ou non, émanant des établissements d'enseignement et de recherche français ou étrangers, des laboratoires publics ou privés. 


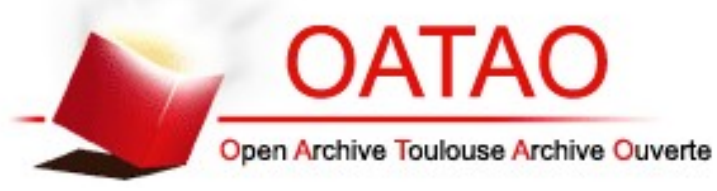

\section{Open Archive Toulouse Archive Ouverte (OATAO)}

OATAO is an open access repository that collects the work of Toulouse researchers and makes it freely available over the web where possible.

This is an author-deposited version published in: http://oatao.univ-toulouse.fr/ Eprints ID: 5697

To link to this article: DOI:10.1016/J.FCT.2010.07.005

URL: http://dx.doi.org/10.1016/J.FCT.2010.07.005

To cite this version: Riba, Amar and Bouras, Nourredine and Mokrane, Salim and Mathieu, Florence and Lebrihi, Ahmed and Sabaou, Nasserdine (2010) Aspergillus section Flavi and aflatoxins in Algerian wheat and derived products. Food and Chemical Toxicology pp. 2772-2777. ISSN 0278-6915

Any correspondence concerning this service should be sent to the repository administrator: staff-oatao@listes.diff.inp-toulouse.fr 


\title{
Aspergillus section Flavi and aflatoxins in Algerian wheat and derived products
}

\author{
Amar Riba $^{\mathrm{a}}$, Noureddine Bouras ${ }^{\mathrm{a}}$, Salim Mokrane ${ }^{\mathrm{a}}$, Florence Mathieu ${ }^{\mathrm{b}}$, Ahmed Lebrihi ${ }^{\mathrm{b}}$, \\ Nasserdine Sabaou ${ }^{\mathrm{a}, *}$ \\ a Laboratoire de Recherche sur les Produits Bioactifs et la Valorisation de la Biomasse, Ecole Normale Supérieure de Kouba, B.P. 92, 16050 Kouba, Alger, Algeria \\ ${ }^{\mathrm{b}}$ Université de Toulouse, Laboratoire de Génie Chimique UMR5503 (CNRS-INPT-UPS), ENSAT-INP de Toulouse, 1 Avenue de l'Agrobiopôle, Castanet-Tolosan Cedex, France
}

\begin{abstract}
A B S T R A C T
Wheat and its derivatives are a very important staple food for North African populations. The aim of this study was to analyze populations of Aspergillus section Flavi from local wheat based on aflatoxins (AFs), cyclopiazonic acid (CPA) and sclerotia production, and also to evaluate AFs-contaminated wheat collected from two different climatic regions in Algeria. A total of 108 samples of wheat were collected during the following phases: pre-harvest, storage in silos and after processing. The results revealed that among the Aspergillus species isolated, those belonging to section Flavi were predominant. Of the 150 strains of Aspergillus section Flavi isolated, 144 were identified as Aspergillus flavus and 6 as Aspergillus tamarii. We showed that $72 \%$ and $10 \%$ of the A. flavus strains produced AFs and CPA, respectively. Among the 150 strains tested, 60 produced amounts of AFB1 ranging from 12.1 to $234.6 \mu \mathrm{g} / \mathrm{g}$ of CYA medium. Also, we showed that most strains produced large sclerotia. AFB1 was detected by HPLC in $56.6 \%$ of the wheat samples and derived products (flour, semolina and bran) with contamination levels ranging from 0.13 to $37.42 \mu \mathrm{g} / \mathrm{kg}$.
\end{abstract}

\section{Introduction}

Contamination of food and feed with mycotoxins represents a high risk for human and animal health. Mycotoxins can cause acute or chronic intoxication and damage to humans and animals after ingestion of contaminated food and feed (Moss, 1996). Furthermore, mycotoxins are responsible for generating huge economic losses in the producing countries (Bhat and Vasanthi, 2003). Pittet (1998) reported that $25-40 \%$ of cereals consumed in the world are contaminated by these toxic compounds. Mycotoxins are secondary metabolites produced by some species of mold genera such as Aspergillus, Penicillium and Fusarium, which enter the food chain in the field, during storage, or later, under favorable conditions of temperature and humidity.

Aflatoxins (AFs) are the most potent natural carcinogens known (JECFA, 1997), affecting animal species, including humans. Four aflatoxins are commonly produced in foods, aflatoxins B1, B2, G1

Abbreviations: AFs, aflatoxins; AFB1, aflatoxin B1; AFPA, Aspergillus flavus parasiticus agar; CAM, coconut agar medium; CPA, cyclopiazonic acid; CYA, Czapek yeast extract agar; CZ, Czapek-Dox agar; DRBC, dichloran rose-bengal chloramphenicol agar; HPLC, high performance liquid chromatography; TLC, thin layer chromatography; MEA, malt extract agar; PDA, potato dextrose agar.

* Corresponding author. Tel.: +21321 2975 11; fax: +21321282067.

E-mail address: sabaou@yahoo.fr (N. Sabaou). and G2. These mycotoxins are produced by Aspergillus flavus, Aspergillus parasiticus, Aspergillus nomius, Aspergillus pseudotamarii, Aspergillus bombycis, Aspergillus toxicarius, Aspergillus minisclerotigenes, Aspergillus parvisclerotigenus and Aspergillus arachidicola in Aspergillus section Flavi (Samson et al., 2006; Pildain et al., 2008). The most important aflatoxin producers from a public health point of view are A. flavus and A. parasiticus. Aflatoxin B1 (AFB1) is often found at the highest concentrations in contaminated food and feed. The most pronounced contamination has been encountered in corn, peanuts, cottonseed and other grain crops (Gourama and Bullerman, 1995).

In North African countries, the foods most susceptible to aflatoxin contamination are locally produced or imported cereals such as wheat. This crop is a staple in dry Mediterranean regions of North Africa, where its consumption in the form of couscous, pasta, macaroni, spaghetti, bread, and frik is a cultural tradition. The mycobiota of wheat and wheat products was found to be dominated by Aspergillus section Nigri and Flavi species (Riba et al., 2008). However, up to now, there has been no systematic study on contamination by AF producing species either on the levels of AFs in wheat consumed in Algeria or on its derivatives. Therefore, the aim of our study was to identify and screen Aspergillus section Flavi isolates for AFs and CPA production, and to evaluate the rates of contamination with aflatoxins in wheat destined for human consumption. 


\section{Materials and methods}

2.1. Study area

The samples were collected from Mitidja and Sétif, two representative regions of the climate of different wheat-producing regions of Algeria. In addition, more than $80 \%$ of Algerian wheat is produced in these two areas. Because of its proximity to the Mediterranean sea, Mitidja (latitude, $36^{\circ} 43^{\prime} \mathrm{N}$; longitude $4^{\circ} 03^{\prime} \mathrm{E}$; altitude, $200 \mathrm{~m}$ ) has a high mean annual rainfall $(700 \mathrm{~mm})$. By contrast, Sétif (latitude, $36^{\circ} 11^{\prime} \mathrm{N}$; longitude, $5^{\circ} 25^{\prime} \mathrm{E}$; altitude, $1081 \mathrm{~m}$ ) has a much lower mean rainfall $(400 \mathrm{~mm})$. These two regions are characterized by a sub-humid and a semi-arid climate, respectively. All together, 108 samples of wheat and its derived products, destined for human consumption, were collected from these two regions: during the seasons of 2004 ( 85 samples) and 2006 (23 samples).

\subsection{Sample collection}

The samples were collected during the following phases of production: pre-harvest (field samples), storage in silos and during processing (in the form of unclean and clean wheat, flour, semolina and bran). The sample collection data are summarized in Table 1.

For the field (pre-harvest) wheat (variety Waha), 27 (seven samples from Mitidja region and 20 samples from Sétif region) and 23 samples (13 samples from Mitidja region and 10 samples from Sétif region) were collected at the maturity stage in July 2004 and July 2006, respectively. The samples were collected along the diagonals of six 1-hectare parcels. Each sample was composed of 40-50 ears, randomly collected from four to five sampling points which were approximately 15-20 m apart.

Thirty-four samples of durum wheat (varieties Waha and Vitron) were collected from silos. In February 2005, 10 and 14 samples of durum wheat were collected after 6 months of storage in silos from Mitidja and Sétif, respectively. Ten samples of wheat stored in silos for 12 months were collected from Mitidja in September 2004. The stored wheat was harvested by combine harvester in many local fields in July 2004. For each sample, a sub-sample of 300-400 g was taken through the "trench-type" silo in a transect at three levels (low, middle and high) and combined to give a sample of about $1 \mathrm{~kg}$ per bin (cylindrical bins of corrugated metal).

From flour and semolina mills, 24 samples (12 per mill) were collected during the mills' routine intake sampling procedure. From each mill, three samples of $1 \mathrm{~kg}$ each were taken at four levels along the production chain: soft wheat (variety HD1220), durum wheat (variety Waha) stored for 9 months in mill bins, clean wheat and products (flour, semolina and bran). The cleaning of wheat consists of eliminating impurities from the grain, hydrothermal treatment and grain sorting. At the moment of collection, the moisture content of durum wheat and soft wheat grain stored in a silo was $12 \% \mathrm{w} / \mathrm{w}$, whereas that of the clean wheat, flour and semolina ranged from $13 \%$ to $14 \% \mathrm{w} / \mathrm{w}$.

After collection in paper bags, the samples were ground to a fine powder using a Waring Blendor at high speed for a short period to avoid overheating of the samples. Aliquots of 100-200 $\mathrm{g}$ were used for the analysis of mycoflora, and the remaining was stored at $-20^{\circ} \mathrm{C}$ for the aflatoxins analysis.

\subsection{Reagents}

All reagents (potassium chloride, phosphoric acid, hydrochloric acid, ammonium hydroxide, $\beta$-cyclodextrin) were of PA grade. All organic solvents (methanol, acetonitrile, 2-propanol, $n$-hexane, chloroform and ethyl-acetate) were of HPLC grade. Deionized water was used for the preparation of all aqueous solutions and for HPLC. Standard toxins, aflatoxins (AFs) and cyclopiazonic acid (CPA) and Ehrlich's reagent $(1 \mathrm{~g}$ of 4-dimethyl-aminobenzaldehyde in $75 \mathrm{ml}$ ethanol and $25 \mathrm{ml}$ concentrated $\mathrm{HCl}$ ) were supplied by Sigma chemicals (France). All other solvents and reagents were of analytical grade purchased from Merck, Germany.

\subsection{Fungal isolates and culture conditions}

Dilution plating was used as the enumeration technique (Pitt and Hocking, 1997). Ten grams of each sample were added to $90 \mathrm{ml}$ of $0.1 \%$ peptone dissolved in water. This mixture was then shaken on a rotary shaker for approximately $15 \mathrm{~min}$ and diluted $10^{2}, 10^{3}$ and $10^{4}$ fold. Aliquots consisting of $0.1 \mathrm{ml}$ of each dilution were spread (in triplicate) on the surface of the Dichloran Rose-Bengal Chloramphenicol Agar medium (DRBC; King et al., 1979) which was composed of: glucose $10 \mathrm{~g} / \mathrm{L}$; peptone $5 \mathrm{~g} / \mathrm{L} ; \mathrm{K}_{2} \mathrm{HPO}_{4} 1 \mathrm{~g} / \mathrm{L} ; \mathrm{MgSO}_{4} \cdot 7 \mathrm{H}_{2} \mathrm{O} 0.5 \mathrm{~g} / \mathrm{L}$; agar $15 \mathrm{~g} / \mathrm{L}$; Rose Bengal $25 \mathrm{mg} / \mathrm{L}$; dichloran (2,6 dichloro-4-nitroaniline) $2 \mathrm{mg} / \mathrm{L}$ and chloramphenicol $100 \mathrm{mg} / \mathrm{L}$. All Petri-dishes were incubated for $3-7$ days at $28{ }^{\circ} \mathrm{C}$ in the dark and under normal atmosphere. One of the three sets of dilutions averaging between 10 and 60 colonies per Petri-dish was selected for enumeration. The results were expressed as average cfu/g. Stock cultures were maintained on PDA tubes and then stored at $4{ }^{\circ} \mathrm{C}$ for subsequent characterization and taxonomic identification procedures.

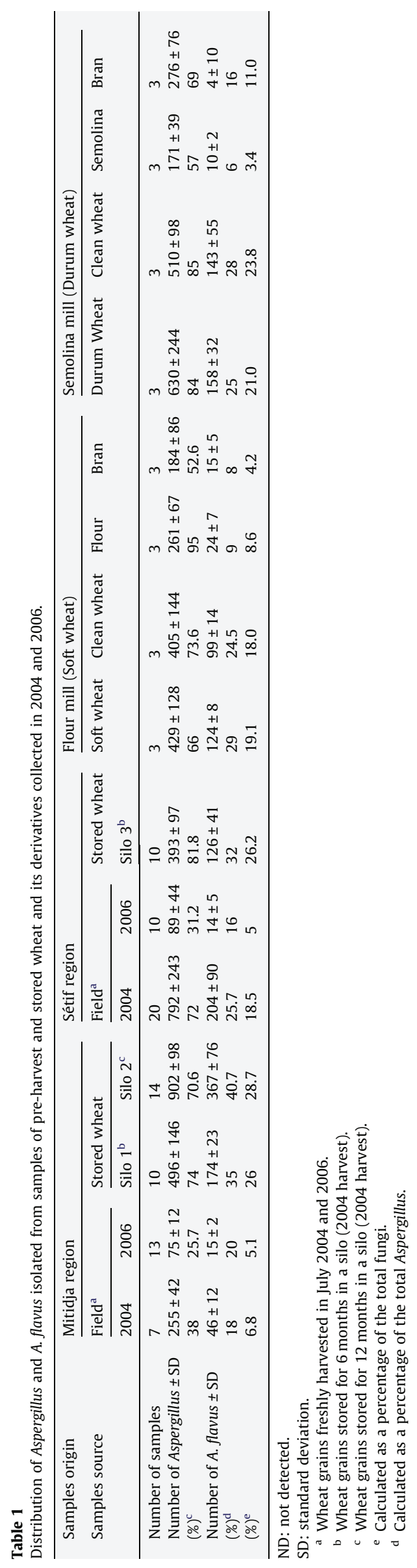




\subsection{Morphological characterization of the isolates}

The colonies of Aspergillus section Flavi from each PDA tube were sub-cultured on $9 \mathrm{~cm}$ diameter Petri dishes containing $20 \mathrm{ml}$ of Malt Extract Agar (MEA) and Czapek-Dox agar (CZ) (per liter): sucrose $30 \mathrm{~g}, \mathrm{~K}_{2} \mathrm{HPO}_{4} 1 \mathrm{~g}, \mathrm{NaNO}_{3} 2 \mathrm{~g}, \mathrm{KCl} 0.5 \mathrm{~g}$, $\mathrm{MgSO}_{4} \cdot 7 \mathrm{H}_{2} \mathrm{O} 0.5 \mathrm{~g}, \mathrm{FeSO}_{4} \cdot 7 \mathrm{H}_{2} \mathrm{O} 0.01 \mathrm{~g}, \mathrm{ZnSO}_{4} \cdot 7 \mathrm{H}_{2} \mathrm{O} 0.01 \mathrm{~g}, \mathrm{CuSO}_{4} \cdot 5 \mathrm{H}_{2} \mathrm{O} 0.005 \mathrm{~g}$ and Agar $20 \mathrm{~g}$ ). Cultures were incubated for 7 days, in the dark, at $25^{\circ} \mathrm{C}$ and then analyzed for colony color, presence and size of sclerotia, head seriation and conidial morphology. For micromorphological observations, the isolates were examined under the microscope $(10 \times, 40 \times$ and $1000 \times$ magnification). Identification was performed according to the taxonomic keys and guides available for the Aspergillus genus (Pitt and Hocking, 1997; Klich, 2002). All isolates were also cultured on Aspergillus flavus parasiticus Agar (AFPA) for $3-5$ days at $25^{\circ} \mathrm{C}$, in the dark, to confirm group identification by colony reverse color. All isolates were also cultured on CZ at $42{ }^{\circ} \mathrm{C}$, and colony diameters were measured after 7 days of incubation (Ehrlich et al., 2007).

\subsection{Mycotoxigenic ability of the isolates}

\subsubsection{Aflatoxins detection}

2.6.1.1. Detection by fluorescence on coconut agar medium. A preliminary screen for aflatoxin production was performed on the basis of emission of blue fluorescence after UV light excitation at $365 \mathrm{~nm}$ after growth of the isolates on Coconut Agar Medium (CAM) supplemented with $0.3 \%$-cyclodextrin (Davis et al., 1987; Fente et al., 2001). One hundred grams of shredded coconut was homogenized for $5 \mathrm{~min}$ with $300 \mathrm{ml}$ of hot distilled water. The homogenate was filtered through four layers of cheesecloth, and the clear filtrate was adjusted to $\mathrm{pH} 7.0$ with $2 \mathrm{~N} \mathrm{NaOH}$ Agar was added $(20 \mathrm{~g} / \mathrm{l})$, and the mixture was sterilized by autoclaving at $120^{\circ} \mathrm{C}$ for $15 \mathrm{~min}$. The isolates were inoculated by the application of a mass of conidia to the central point on a $60 \mathrm{~mm}$ diameter Petri dish containing $10 \mathrm{ml}$ of CAM. The cultures were incubated at $28{ }^{\circ} \mathrm{C}$ for a period of 7 days, and for the appearance of colonies with brilliant orange-yellow reverse coloration under daylight and blue fluorescence under long wavelength ( $365 \mathrm{~nm}$ ) UV light was periodically verified. A blank consisting of sterilized, non-inoculated CAM medium, incubated under the same conditions, was used as control.

2.6.1.2. Detection by TLC. Thin layer chromatography (TLC) was used as a screening method to identify the positive samples essentially as described by Calvo et al (2004). For this, four cores (16-mm diameter) corresponding to $2 \mathrm{~g}$ of fungal biomass were collected from each replicate of CAM cultures and placed in a $50-\mathrm{ml} \mathrm{Fal-}$ con tube. AFs were extracted from these samples by adding $5 \mathrm{ml}$ of chloroform three consecutive times. Extracts were allowed to dry and then re-suspended in $500 \mu \mathrm{l}$ of chloroform. A volume of $15 \mu \mathrm{l}$ of each extract was applied on a silica gel $\mathrm{G}_{60}$ plate $(20 \times 20 \mathrm{~cm}, 0.25 \mathrm{~mm}$ thick, Merck 5721, Germany), along with standard AFs mixture (containing AFB1 and AFG1 at $0.5 \mu \mathrm{g} / \mathrm{ml}$ each and AFB2 and AFG2 at $0.15 \mu \mathrm{g} / \mathrm{ml}$ each). The plates were developed in a benzene/glacial acetic acid $(95: 5, \mathrm{v} / \mathrm{v})$ solvent system. After development, the plates were dried and observed under short $(254 \mathrm{~nm})$ and long wavelengths $(365 \mathrm{~nm})$. The detection limit was $0.05 \mu \mathrm{g} / \mathrm{g}$ for all the AFs. The AFs were detected as an intense blue and green fluorescence spot for AFB and AFG, respectively, with the $R_{\mathrm{f}}$ values of $0.8,0.6,0.5$ and 0.4 for AFB1, AFB2, AFG1 and AFG2, respectively.

2.6.1.3. Detection by HPLC. High performance liquid chromatography (HPLC) was used to confirm the identity of the AFs and to quantify them. AFs production by isolated fungal strains was determined using HPLC following the methodology described by Bragulat et al. (2001). After 7 days of growth of isolates on Czapek yeast extract agar (CYA) at $28{ }^{\circ} \mathrm{C}$, three agar plugs (10 $\mathrm{mm}$ in diameter) were removed, with a cork borer, from the central area of each colony. Plugs were weighted and introduced into $3 \mathrm{ml}$ vials and extracted with $1 \mathrm{ml}$ of methanol for $1 \mathrm{~h}$. The extracts were centrifuged at $13,000 \mathrm{rpm}$ for $10 \mathrm{~min}$ at $4{ }^{\circ} \mathrm{C}$ and filtered through a $0.45 \mu \mathrm{m}$ hydrophilic PVDF filter (Millipore).

The presence of aflatoxins was detected by high performance liquid chromatography (HPLC) using a post-column derivatization electrochemically generated bromine (Kobra cell) and a fluorescence detector (Spectra physic 2000) $(\lambda=362 \mathrm{~nm}$ excitation, $\lambda=435 \mathrm{~nm}$ emission). The HPLC column used was a reverse phase RP C18 ProntoSil analytical column $(250 \times 4 \mathrm{~mm}, 3 \mu \mathrm{m}$ particle size $)$ preceded by a C18 pre-column (Ultrasep $10 \times 4 \mathrm{~mm}$ ) and the flow rate was $0.5 \mathrm{ml} / \mathrm{min}$. For post-column derivatization, $119 \mathrm{mg}$ potassium bromide and $350 \mu \mathrm{l}$ of $4 \mathrm{M}$ nitric acid were added to $1 \mathrm{l}$ of the mobile phase (20:20:60 (v/v) acetonitrile/methanol/ water), as suggested in the Kobra cell instruction manual. The system was run isocratically, with a flow rate of $0.5 \mathrm{ml} / \mathrm{min}$; the elution times for AFB1, AFB2, AFG1 and AFG2 were 30.2, 24.1, 22.5 and $21.4 \mathrm{~min}$, respectively. The chromatograms were analyzed with Class-LC10 software version 1.6 (Shimadzu). The limit of detection was $0.005 \mu \mathrm{g} / \mathrm{kg}$ for AFB1 and AFG1, and $0.02 \mu \mathrm{g} / \mathrm{kg}$ for AFB2 and AFG2.

\subsubsection{Cyclopiazonic acid detection}

The isolates were tested for cyclopiazonic acid (CPA) production on CYA medium following the method described by Pildain et al. (2004). All strains were inoculated on $90 \mathrm{~cm}$ diameter Petri dishes and incubated at $28^{\circ} \mathrm{C}$. After 10 days, $2 \mathrm{~g}$ of fungal biomass was extracted by adding $5 \mathrm{ml}$ of chloroform, three consecutive times. Extracts were allowed to dry and then re-suspended in $500 \mu \mathrm{l}$ of methanol, and filtered through a $0.45 \mu \mathrm{m}$ hydrophilic PVDF filter (Millipore).

Crude extract samples were applied to TLC on silica gel plates as above. To determine the detection limit, a series of different concentrations $(0.5,1,10,25$ and $50 \mu \mathrm{g} / \mathrm{ml}$ ) of CPA dissolved in methanol was prepared and a volume of $20 \mu \mathrm{l}$ of each was applied to a silica gel TLC. Twenty microliter of standard and each extract (re-dissolved in $500 \mu \mathrm{l}$ of methanol) were applied to a silica gel TLC plate, which was previously impregnated with a solution of oxalic acid ( $2 \%$ in methanol) for $2 \mathrm{~min}$ and dried. The plates were run in the same direction with ethyl acetate/2propanol/ammonium hydroxide (40:30:20, v/v) (Fernandez Pinto et al., 2001). After pulverization of the plates with Ehrlich's reagent, the CPA was detected under daylight as an intense purple spot with an $R_{\mathrm{f}}$ of 0.5 . The detection limit of the TLC technique was $1 \mu \mathrm{g} / \mathrm{g}$.

\subsection{Analysis of AFs in wheat and wheat products}

\subsubsection{Extraction of $A F s$}

The extraction of AFs from wheat samples was performed according to El Adlouni et al. (2006). Briefly, $20 \mathrm{~g}$ of fine powdered samples were added to $20 \mathrm{ml}$ of $4 \%$ potassium chloride solution acidified to $\mathrm{pH} 1.5$ with sulfuric acid. The mixture was homogenized and extracted with $180 \mathrm{ml}$ acetonitrile on an orbital shaker for $20 \mathrm{~min}$, and filtered through No. 4 Whatman paper.

\subsubsection{Purification of the extract}

The $n$-hexane $(100 \mathrm{ml})$ was added to the filtrate and shaken for $1 \mathrm{~min}$. After separation, the upper phase ( $n$-hexane) was discarded. To the lower phases, $50 \mathrm{ml}$ deionized water and $100 \mathrm{ml}$ chloroform were added. The mixture was shaken for $10 \mathrm{~min}$. After separation, the lower phase (chloroform) was collected. The upper phase was re-extracted three times with $20 \mathrm{ml}$ of chloroform using the above conditions. To the pooled chloroform extracts, $50 \mathrm{ml}$ of $5 \%$ sodium bicarbonate was added and shaken for $10 \mathrm{~min}$. The upper phase (bicarbonate) was collected, acidified to $\mathrm{pH} 1.5$ with concentrated hydrochloric acid and allowed to stand about $20 \mathrm{~min}$. The acidified solution was extracted three times with chloroform (100 50 and $50 \mathrm{ml}$ ). The pooled chloroform phases were evaporated to near dryness under vacuum using a rotary evaporator placed in a $40{ }^{\circ} \mathrm{C}$ water bath. The extract was re-suspended in $1 \mathrm{ml}$ of methanol, sonicated and filtered through a $0.2 \mu \mathrm{m}$ Minisart cartridge (Sartorius AG Goettingen, Germany). The analysis was performed using the method previously described (Section 2.6.1.).

\subsubsection{Determination of the rate of AFB1 recovery}

The rate of AFB1 recovery was determined by spiking an AFB1-free sample ( $50 \mathrm{~g}$ of ground wheat) with an equivalent of $0.5,5.0,10$ and $20 \mu \mathrm{g} / \mathrm{kg}$ of AFB1, from a $10 \mu \mathrm{g} / \mathrm{ml}$ stock solution of AFB1 dissolved in methanol. Spiking was carried out in triplicates and a single analysis of a blank sample was also carried out. After allowing the methanol solvent to evaporate overnight, AFB1 was extracted as described above. The percentage of AFB1 recovery was calculated and taken into account for the determination of AFB1 levels in analyzed samples.

\section{Results}

\subsection{Distribution of isolates of Aspergillus section Flavi}

The fungal strains isolated from 108 samples (pre-harvest, in a state of storage and from flour and semolina mills) collected in 2004 and 2006 are shown in Table 1. The results revealed the dominance of Aspergillus species from all the samples analyzed with the mean percentage of $64.5 \%$. Regarding Aspergillus section Flavi isolation, the mean percentage found was $22.5 \%$ of the total Aspergillus and $15.1 \%$ of the total fungi. The other species isolated belonged to the Aspergillus section Nigri, Circumdati and Terrei. Colonization of wheat by species belonging to Aspergillus section Flavi was higher in stored samples $(26 \%, 26.2 \%$ and $28.7 \%$ ) compared to the field samples (5\%, 5.1\%, $6.8 \%$ and $18.5 \%)$. The soft and durum wheat from mills contained levels of these species ranging from $3.4 \%$ to $23.8 \%$ with a mean of $13.6 \%$ of the total fungi. These species were isolated at a low frequency from wheat products (flour, semolina and bran).

\subsection{Identification of strains of Aspergillus section Flavi}

Among the total strains of Aspergillus section Flavi isolated from wheat and its derivatives (flour, semolina and bran), 150 were chosen for their AFs, CPA production and sclerotia characterization. 
Aspergillus strains belonging to the section Flavi were identified preliminarily at the species level, based on morphological characteristics (mainly colony color on Czapek-Dox agar and conidia morphology). Of the 150 strains of Aspergillus section Flavi collected from wheat, 144 were identified as presumptive A. flavus and 6 as Aspergillus tamarii. The 144 isolates of A. flavus displayed typical morphological features of yellow-green colonies with smooth to finely rough globose conidia. The reverse sides of colonies of $A$. flavus strains were of a bright orange color on Aspergillus flavus parasiticus agar (AFPA) plates and could grow at $42^{\circ} \mathrm{C}$. By contrast, the 6 isolates identified as A. tamarii were of brown-to-dark-brown color and produced rough conidia. Moreover, colonies of $A$. tamarii could not grow at $42^{\circ} \mathrm{C}$.

\subsection{Aflatoxin production by isolates of Aspergillus section Flavi}

The capacity for producing AFs was determined for 150 isolates collected in 2004 and 2006 from wheat and its derivatives. Initially, aflatoxin production was screened on Coconut Agar Medium (CAM), and the results showed that 45 isolates (30\%) were aflatoxigenic. HPLC analysis revealed that among the 150 strains tested, 108 (72\%) were AFB1 producers. The results concerning the per-

\section{Table 2}

Occurrence and AFB1-producing ability of 150 isolates of Aspergillus section Flavi isolated from samples of pre-harvest, stored wheat and its derivatives collected in 2004 and 2006.

\begin{tabular}{lll}
\hline AFB1 $(\mu \mathrm{g} / \mathrm{g})^{\mathrm{a}}$ & No. of strains & Percentage $(\%)$ \\
\hline$<0.005$ & 42 & 28 \\
$0.005-0.1$ & 40 & 27 \\
$0.11-10.0$ & 8 & 5 \\
$10.1-100$ & 37 & 25 \\
$>100$ & 23 & 15
\end{tabular}

a The amounts of AFB1 were calculated after 7 days of growth on CYA at $28{ }^{\circ} \mathrm{C}$ and analyzed by HPLC.

Table 3

Chemotype patterns of Aspergillus section Flavi strains on aflatoxins, cyclopiazonic acid and sclerotia producing ability.

\begin{tabular}{lllllll}
\hline Chemotype & \multicolumn{2}{l}{ Mycotoxins } & & Sclerotia & $\begin{array}{l}\text { No. of } \\
\text { strains }\end{array}$ & Percentage (\%) \\
\cline { 2 - 4 } & AFB1 & AFGI & CPA & & & \\
\hline I & - & - & - & - & 45 & 30 \\
II & + & - & - & - & 45 & 30 \\
III & - & - & - & + & 30 & 20 \\
IV & + & - & - & + & 15 & 10 \\
V & + & - & + & $+^{\mathrm{a}}$ & 6 & 4 \\
VI & + & - & + & - & 3 & 2 \\
VII & - & - & + & - & 4 & 2.7 \\
VIII & - & - & + & + & 2 & 1.3 \\
\hline
\end{tabular}

AFB1: aflatoxin B1; AFG1: aflatoxin G1; CPA: cyclopiazonic acid.

a Only one strain (chemotype $\mathrm{V}$ ) was able to produce the S-type sclerotia.

b Percentage of the 150 isolates. centage of AFB1-producing ability of Aspergillus section Flavi strains on CYA medium are shown in Table 2.

Isolates of Aspergillus section Flavi were randomly classified into five groups according to their capacity for producing AFB1, which ranged from 0.02 to $234 \mu \mathrm{g} / \mathrm{g}$ of medium (Table 2). Twenty-three isolates (15\%) presented high aflatoxigenic capacity with mean levels of AFB1 ranging from 103 to $234.6 \mu \mathrm{g} / \mathrm{g}$, and 37 (25\%) were moderately aflatoxigenic (12.1-95.7 $\mu \mathrm{g} / \mathrm{g}$ of medium) as demonstrated by HPLC analysis. Furthermore, we observed that a total of 40 strains (27\%) were able to produce small quantities of AFB1 in the $0.02-0.09 \mu \mathrm{g} / \mathrm{g}$ range. Similarly, we observed that the high producers of AFB1 (greater than $100 \mu \mathrm{g} / \mathrm{g}$ ) were also AFB2 producers $(4-125 \mu \mathrm{g} / \mathrm{g})$. However, none of the 42 isolates (28\%) produced AFB1 at the detectable limit $(5 \mu \mathrm{g} / \mathrm{g})$ and no AFG production was detected in any of the 150 isolates analyzed.

\subsection{Identification of chemotypes in Aspergillus section Flavi}

Based on mycotoxin production patterns (AFB1, AFG and CPA) and formation of sclerotia, the 150 strains were classified into eight chemotypes (Table 3). Chemotype I was represented by 45 isolates (30\%) non-producing of any mycotoxins or sclerotia; chemotype II was represented by 45 isolates (30\%), which produced only AFB1; chemotype III was represented by 30 isolates (20\%), which only present sclerotia; chemotype IV was represented by 15 isolates (10\%), which produced both AFB1 and sclerotia; chemotype V was represented by six isolates, which were able to produce AFB1, CPA and sclerotia, including one isolate which produced small sclerotia $(<400 \mu \mathrm{m})$; chemotype VI was represented by three isolates, which produced both AFB1 and CPA; chemotype VII was represented by four isolates, which were able to produce only $\mathrm{CPA}$; and chemotype VIII was represented by only two isolates, which produced CPA and sclerotia.

\subsection{Aflatoxin content in wheat and wheat products}

The incidence and level of AFB1 contamination in pre-harvest and stored wheat are summarized in Table 4. AFB1 was detected in 30 of the 53 samples examined (or an incidence of 56.6\%). The incidence of contamination in 2004 and 2006 was 53.3\% and $60.9 \%$, respectively, with concentrations ranging from 0.13 to $37.42 \mu \mathrm{g} / \mathrm{kg}$. The high level of AFB1 $(37.4 \mu \mathrm{g} / \mathrm{kg})$ was found in sample wheat stored for 12 months. In the processing chain, AFB1was detected only in bran of flour mill $(3.37 \mu \mathrm{g} / \mathrm{kg})$ and semolina $(1.18 \mu \mathrm{g} / \mathrm{kg})$. Of the 53 samples analyzed, five (9.4\%) were above the legal limit established by EU regulations $(5 \mu \mathrm{g} / \mathrm{kg}$ ) (European commission, 2006) and two samples were above the legal limit as recognized in Algeria $(10 \mu \mathrm{g} / \mathrm{kg})(\mathrm{FAO}, 2004)$.

\section{Discussion}

Wheat is one of the world's most important food crops. Foods made from wheat and its derivatives are a major part of a diet

\section{Table 4}

Incidence and range of AFB1 level in samples of pre-harvest and stored wheat collected from the Mitidja and Sétif regions (Algeria) in 2004 and 2006.

\begin{tabular}{|c|c|c|c|c|c|c|c|}
\hline \multirow{3}{*}{$\begin{array}{l}\text { Samples origin } \\
\text { Samples source } \\
\text { Season }\end{array}$} & \multicolumn{4}{|c|}{ Mitidja region } & \multicolumn{3}{|c|}{ Sétif region } \\
\hline & \multicolumn{2}{|l|}{ Field } & \multicolumn{2}{|c|}{ Stored wheat } & \multicolumn{2}{|l|}{ Field } & \multirow{2}{*}{$\begin{array}{l}\text { Stored wheat } \\
\text { Silo } 3\end{array}$} \\
\hline & 2004 & 2006 & Silo 1 & Silo 2 & 2004 & 2006 & \\
\hline Number of samples analyzed & 3 & 13 & $6^{\mathrm{a}}$ & $5^{\mathrm{a}}$ & $2^{\mathrm{b}}$ & 10 & $6^{\mathrm{a}}$ \\
\hline Number of positive samples & 2 & 8 & 5 & 4 & 1 & 6 & 2 \\
\hline Amount of AFB1 in positive samples $(\mu \mathrm{g} / \mathrm{kg})$ & $1.35 ; 3.41$ & $0.22-13.96$ & $0.31-4.62$ & $1.69-37.42$ & 0.87 & $0.21-7.0$ & $0.13 ; 0.44$ \\
\hline
\end{tabular}

\footnotetext{
a Each sample represents one bin of silo.

b Each sample represents the 10 pooled sub-samples collected in one land parcel.
} 
for over a third of the world's people. In Algeria, climatic conditions characterized by high humidity and temperature and inadequate storage practices contribute to the potential for significant exposure of the Algerian population to AFs. In our previous study (Riba et al., 2008), species of Fusarium, Penicillium, Alternaria and Mucor and especially Aspergillus (belonging to section Flavi and Nigri) were the major fungal species most commonly isolated from Algerian wheat. The presently available data confirm that the genus Aspergillus displays a worldwide distribution, particularly in subtropical and warm temperate regions such as North Africa (Hocking and Pitt, 2003).

Among all the strains screened, we could not find any AFG producer. This observation suggests the absence of AFG-producing species (A. parasiticus, A. nomius, A. bombycis, A. toxicarius, and A. arachidicola) in the analyzed samples. On the other hand, Ehrlich et al. (2007) reported that $A$. pseudotamarii is characterized by a brown to dark-brown color, and is not able to grow at $42^{\circ} \mathrm{C}$. However, our results showed that all the AF-producers have yellowgreen colonies and are able to grow at $42^{\circ} \mathrm{C}$. This observation suggests the absence of this species in our samples. In our study, the one strain producing small sclerotia produce only AFB and CPA. This strain does not obviously belong to A. minisclerotigenes or to A. parvisclerotigenus, which produce both AFB and AFG (Pildain et al., 2008). Thus, we can conclude that $A$. flavus is the only aflatoxigenic fungus in Algerian wheat. It is known that A. flavus strains are commonly associated with warmer geographical regions. Indeed, several studies reported the predominance of this species in wheat samples originating from Argentina (Vaamonde et al., 2003), Australia (Berghofer et al., 2003), Egypt (Abdel Hafez et al., 1990; Mazen et al., 1984), Iran (Ghiasian et al., 2004), and Turkey (Baydar et al., 2005). In addition, although aflatoxin-production ability has been detected in a variety of species of the Aspergillus genus, inside and outside the Flavi section, A. flavus and $A$. parasiticus remain the most important and representative AF-producers occurring naturally in food commodities.

Of the 150 strains examined, 108 (72\%) produced AFB1 in amounts ranging from 0.02 to $234.6 \mu \mathrm{g} / \mathrm{g}$ of CYA medium. The percentage of aflatoxigenic strains of A. flavus has been shown to vary with the nature of substrate, and environmental factors (Horn, 2003; Klich, 2007). For example, the incidence of aflatoxigenic $A$. flavus strains was higher in peanuts $(69 \%)$ than in wheat $(13 \%)$ (Vaamonde et al., 2003). In addition, among Aspergillus isolates, there is great variation in aflatoxin production especially within the most common aflatoxin-producing species, A. flavus (Abbas et al., 2005).

Our strains were classified into eight different chemotypes, based on patterns of mycotoxin (AFB1, AFG and CPA) and sclerotial production. The results obtained demonstrate a great variability in the AFB and CPA-producing potential of A. flavus. According to Pitt (1993), A. flavus isolates produce AFB1 and AFB2, CPA alone, AFB1, AFB2 and CPA or neither. Our results showed that only $10 \%$ of isolates are able to produce CPA. We observed that only 9 isolates (6\%) of A. flavus were able to simultaneously produce AFB1 and CPA. In contrast, Frisvad et al. (2005) reported that production of CPA is correlated with AFB1 production. Giorni et al. (2007) showed that $70 \%$ of A. flavus isolated from Italian maize are producers of AFs, and that half of them are CPA producers.

Our results showed that only 21 aflatoxigenic strains (14\%) are able to produce sclerotia (chemotypes IV and V). Several authors suggested that the size and formation of sclerotia are correlated to the aflatoxigenicity of isolates (Cotty, 1989; Criseo et al., 2001). It is currently known that all S-type strains, with small sclerotia $(<400 \mu \mathrm{m}$ in diameter) are aflatoxigenic. However, L-type strains, with larger sclerotia ( $>400 \mu \mathrm{m}$ in diameter), usually include both aflatoxigenic and non-aflatoxigenic strains. Many authors reported that the S-type strains are rarely isolated
(Vaamonde et al., 2003; Barros et al., 2005; Giorni et al., 2007) and are usually obtained from geographical regions characterized by high temperatures and low rainfall (Cardwell and Cotty, 2002).

Of the 53 samples of wheat and wheat products analyzed, 57.1\% were contaminated by AFB1 and two samples were not safe for human consumption according to the national limits $(10 \mu \mathrm{g} / \mathrm{kg})$. Our results are in line with those reported by Perenzin et al. (2001) who found that $62 \%$ of wheat samples collected from experimental field plots in northern Italy (Lombardy) were contaminated by aflatoxins. In contrast, Jiménez and Mateo (2001) reported that although aflatoxigenic fungi were found at high levels in wheat, no aflatoxins were found in 165 samples collected from markets in Spain. Although the number of samples analyzed was limited, our results revealed a relatively high contamination of wheat grain comparing to wheat products. Therefore, it can be hypothesized that during processing, the quantity of mycotoxins is reduced as observed for the species belonging to Aspergillus section Flavi. Zinedine et al. (2007) reported that the incidence of AFB1 in wheat flour commercialized in Morocco was about $17.6 \%$, and that levels of contamination ranged from 0.03 to $0.15 \mu \mathrm{g} / \mathrm{kg}$. According to Behfar et al. (2008), none of 32 wheat flour samples was contaminated by aflatoxins. Some food processing methods have been shown to result in reduction or elimination of aflatoxins (Murphy et al. 2006). These results reveal the widespread occurrence of aflatoxigenic strains of A. flavus in Algeria, and highlight the importance of the post-harvest care of grains. Thus, whenever there is a problem in the storage or in the processing of wheat and wheat-based feeds that allows fungal growth, the risk of mycotoxin contamination should be taken into account. More investigations on levels of AFs in different food products are necessary to provide data on the exposure of the Algerian population to AFs.

\section{Conflict of Interest}

The authors declare that there are no conflicts of interest.

\section{References}

Abbas, H.K., Weaver, M.A., Zablotowicz, R.M., Horn, B.W., Shier, W.T., 2005. Relationships between aflatoxin production and sclerotia formation among isolates of Aspergillus section Flavi from the Mississippi Delta. Eur. J. Plant Pathol. 112, 283-287.

Abdel Hafez, S.I., Moubasher, A.H., Shoreit, A.A., Ismail, M.A., 1990. Fungal flora associated with combine harvester wheat and sorghum dusts from Egypt. J. Basic Microbiol. 30, 467-479.

Barros, G., Torres, A., Sofıa Chulze, S., 2005. Aspergillus flavus population isolated from soil of Argentina's peanut-growing region. Sclerotia production and toxigenic profile. J. Sci. Food Agric. 85, 2349-2353.

Baydar, T., Engin, A.B., Girgin, G., Aydin, S., Sahim, G., 2005. Aflatoxin and ochratoxin in various types of commonly consumed retail ground samples in Ankara, Turkey. Ann. Agric. Environ. Med. 12, 193-197.

Behfar, A., Nazari Khorasgani, Z., Mosavi, A., 2008. Determination of aflatoxin (B1, B2, G1, G2) levels in wheat flour. Toxicol. Lett. 180S, S32-S246 (Abstract)

Berghofer, L.K., Hocking, A.D., Miskelly, D., Jansson, E., 2003. Microbiology of wheat and flour milling in Australia. Int. J. Food Microbiol. 85, 137-149.

Bhat, R.V., Vasanthi, S., 2003. Mycotoxin food safety risks in developing countries. Food Safety in Food Security and Food Trade. Vision 2020 for Food, Agriculture and Environment, Focus 10, brief 3 of 17, pp. 1-2.

Bragulat, M.R., Abarca, M.L., Cabanes, F.J., 2001. An easy screening method for fungi producing ochratoxin A in pure culture. Int. J. Food Microbiol. 71, 139-144.

Calvo, A.M., Bok, J., Brooks, W., Keller, N.P., 2004. VeA is required for toxin and sclerotial production in Aspergillus parasiticus. Appl. Environ. Microbiol. 70, 4733-4739.

Cardwell, K.F., Cotty, P.J., 2002. Distribution of Aspergillus section Flavi among field soils from the four agroecological zones of the Republic of Benin West Africa. Plant Dis. 86, 434-439.

Cotty, P.J., 1989. Virulence and cultural characteristics of two Aspergillus flavus strains pathogenic on cotton. Phytopathology 79, 808-814.

Criseo, G., Bagnara, A., Bisignano, G., 2001. Differentiation of aflatoxin-producing and non-producing strains of Aspergillus flavus group. Lett. Appl. Microbiol. 33, 291-295.

Davis, N.D., Iyer, S.K., Diener, U.L., 1987. Improved method of screening for aflatoxin with a coconut agar medium. Appl. Environ. Microbiol. 53, 1593-1595. 
Ehrlich, K.C., Kobbeman, K., Montalbano, B.G., Cotty, P.J., 2007. Aflatoxin producing Aspergillus species from Thailand. Int. J. Food Microbiol. 114, 153-159.

El Adlouni, C., Tozlovanu, M., Naman, F., Faid, M., Pfohl-Leszkowicz, A., 2006. Preliminary data on the presence of mycotoxins (ochratoxin A, citrinin and aflatoxin B1) in black table olives "Greek style" of Moroccan origin. Mol. Nutr. Food Res. 50, 507-512.

European Commission, 2006. Commission Regulation No. 1881/2006 of December 19th (2006). Setting maximum levels of certain contaminants in foodstuffs. Official Journal of the European Union No. L364/5 of December 20th.

FAO (Food and Agriculture Organization of the United Nations), 2004. Worldwide Regulations for Mycotoxins in Food and Feed in 2003. FAO Food and Nutrition paper, vol. 81. FAO, Rome.

Fente, C.A., Ordaz, J.J., Vazquez, B.I., Franco, C.M., Cepeda, A., 2001. New additive for culture media for rapid identification of aflatoxin-producing Aspergillus strains. Appl. Environ. Microbiol. 67 (48), 58-62.

Fernandez Pinto, V., Patriarca, A., Locani, O., Vaamonde, G., 2001. Natural cooccurrence of aflatoxin and cyclopiazonic acid in peanuts grown in Argentina. Food Addit. Contam. 18, 1017-1020.

Frisvad, J.C., Skouboe, P., Samson, R.A., 2005. Taxonomic comparison of three different groups of aflatoxin producers and a new efficient producer of aflatoxin B1, sterigmatocystin and 3-omethylsterigmatocyst in: Aspergillus rambellii sp. nov.. Syst. Appl. Microbiol. 28, 442-453.

Ghiasian, S.A., Kord-Bacheh, P., Rezayat, S.M., Maghsood, A.H., Taherkhani, H., 2004. Mycoflora of Iranian maize harvested in the main production areas in. Mycopathologia 158, 113-121.

Giorni, P., Magan, N., Pietri, A., Bertuzzi, T., Battilani, P., 2007. Studies on Aspergillus section Flavi isolated from maize in northern Italy. Int. J. Food Microbiol. 113, 330-338.

Gourama, H., Bullerman, L.B., 1995. Aspergillus flavus and Aspergillus parasiticus, aflatoxigenic fungi of concern in foods and feed - a review. J. Food Protect. 58, 1395-1404.

Hocking, A.D., Pitt, J.I., 2003. Mycotoxigenic fungi. In: Hocking, A.D. (Ed.), Foodborne Microorganisms of Public Health Significance, sixth ed. Australian Institute, Sydney.

Horn, B.W., 2003. Ecology and population biology of aflatoxigenic fungi in soil. J. Toxicol. Toxin Rev. 22, 351-379.

JECFA (Joint expert committee on food and additives), 1997. Evaluation of Certain Food Additives and Contaminants. Forty-sixth Report of the Joint FAO/WHO Expert Committee on Food Additives 1996. WHO Technical Report Series 868. Geneva: World Health Organization.

Jiménez, M., Mateo, R., 2001. Occurrence of Toxigenic Fungi and Mycotoxins in Agricultural Commodities in Spain. In: Logrieco, A. (Ed.), Occurrence of
Toxigenic Fungi and Mycotoxins in Plants, Food and Feeds in Europe, European Commission, COST Action 835, EUR 19695, pp. 173-190.

King, A.D., Hocking, A.D., Pitt, J.I., 1979. Dichloran-rose bengal medium for enumeration and isolation of molds from foods. Appl. Environ. Microbiol. 37, 959-964.

Klich, M.A., 2002. Identification of common Aspergillus species, Utrecht. Centraalbureau voor Schimmelcultures, Netherlands.

Klich, M.A., 2007. Environmental and developmental factors influencing aflatoxin production by Aspergillus flavus and Aspergillus parasiticus. Mycoscience 48, 7180.

Mazen, M.B., Abdel-Hafez, S.I.I., Shaban, G.M., 1984. Survey of the mycoflora of Egyptian wheat grain and their lemmae and paleae. Mycopathologia 85, 155159.

Moss, M.O., 1996. Mode of formation of ochratoxin A. Food Addit. Contam. 13S, 5-9.

Murphy, P.A., Hendrich, S., Landgren, C., Bryant, C.M., 2006. Food mycotoxins, an update. J. Food Sci. 71 (5), 51-65.

Perenzin, M., Cattaneo, M., Rizzi, E., Pedrotti, A., Tonesi, R., 2001. Frumento tenero biologico: Risultati agronomici equalitativi. L'Informatore agrario 33, 31-33.

Pildain, M.B., Frisvad, J.C., Vaamonde, G., Cabral, D., Varga, J., Samson, R.A., 2008. Two novel aflatoxin-producing Aspergillus species from Argentinean peanuts. Int. J. Syst. Evol. Microbiol. 58, 725-735.

Pildain, M.B., Vaamonde, G., Cabral, D., 2004. Analysis of population structure of Aspergillus flavus from peanut based on vegetative compatibility, geographic origin: mycotoxin and sclerotia production. Int. J. Food Microbiol. 93, 31-40.

Pitt, J.I., Hocking, A.D., 1997. Fungi and Food Spoilage. Blackie Academic and Professional, London.

Pitt, R.E., 1993. A descriptive model of mold growth and aflatoxin formation as affected by environmental conditions. J. Food Protect. 56, 139-146.

Pittet, A., 1998. Natural occurrence of mycotoxins in food and feeds - an updated review. Rev. Med. Vet. 149, 479-492.

Riba, A., Mokrane, S., Mathieu, F., Lebrihi, A., Sabaou, N., 2008. Mycoflora and ochratoxin A producing strains of Aspergillus in Algerian wheat. Int. J. Food Microbiol. 122, 85-92.

Samson, R.A., Hong, S.B., et Frisvad, J.C., 2006. Old and new concepts of species differentiation in Aspergillus. Med. Mycol. 44, 133-148.

Vaamonde, G., Patriarca, A., Fernandez Pinto, V., Comerio, R., Degrossi, C., 2003. Variability of aflatoxin and cyclopiazonic acid production by Aspergillus section Flavi from different substrates in Argentina. Int. J. Food Microbiol. 88, 79-84.

Zinedine, A., González-Osnaya, L., Soriano, J.M., Moltó, J.C., Idrissi, L., Mañes, J., 2007. Presence of aflatoxin M1 in pasteurized milk from Morocco. Int. J. Food Microbiol. 114, 25-29. 